\title{
JUDICIALIZAÇÃO DA POLÍTICA E CONTROLE JUDICIAL DE POLÍTICAS PÚBLICAS
}

\author{
Estefânia Maria de Queiroz Barboza e Katya Kozicki
}

JUDICIALIZATION OF POLITICS AND THE JUDICIAL REVIEW OF PUBLIC POLICIES

\section{RESUMO}

O PRESENTE ARTIGO ANALISA A JUDICIALIZAÇÃO DA POLÍTICA, DEMONSTRANDO QUE NÃO SE TRATA APENAS DE UM FENÔMENO BRASILEIRO, MAS DE ALGO COMUM A DIVERSOS PAÍSES OCIDENTAIS. ESSE MOVIMENTO TEM SOFRIDO SEVERAS CRÍTICAS, QUE QUESTIONAM A SUA LEGITIMIDADE E APONTAM O ESVAZIAMENTO DA ESFERA POLÍTICA. EM CONTRAPONTO, É TRAÇADO UM PARALELO COM A DOUTRINA DA AUTORRESTRIÇÃO JUDICIAL, A QUAL DEFENDE QUE AS QUESTÕES POLÍTICAS DEVEM SER ENFRENTADAS PELOS PODERES ELEITOS. POR FIM, PROCURA-SE DEMONSTRAR, POR MEIO DA ANÁLISE DE DECISÕES DO STF E DO STJ, COMO O PODER JUDICIÁRIO BRASILEIRO TEM SE MANIFESTADO EM QUESTÕES DE POLÍTICAS PÚBLICAS, DE MODO A REALIZAR OS DIREITOS FUNDAMENTAIS PLASMADOS NA CARTA DE 1988.

\section{PALAVRAS-CHAVE}

JURISDIÇÃO CONSTITUCIONAL; JUDICIALIZAÇÃO DA POLÍTICA; AUTOCONTENÇÃO JUDICIAL; CONTROLE JUDICIAL; POLÍTICAS PÚBLICAS.

\section{ABSTRACT}

THIS PAPER AIMS TO ANALYZE THE SO-CALLED JUDICIALIZATION OF POLITICS, SHOWING THAT IT IS NOT JUST A BRAZILIAN EXPERIENCE, BUT A COMMON ONE IN SEVERAL WESTERN COUNTRIES. THIS MOVEMENT HAS BEEN VERY CRITICIZED CONCERNING ITS POLITICAL LEGITIMACY AND THE EXHAUSTION OF POLITICAL SPHERE. FROM THE OTHER HAND THE ARTICLE ANALYZES THE THEORY OF JUDICIAL RESTRAINT, WHICH DEFENDS THAT POLITICAL QUESTIONS SHOULD BE DECIDED BY ELECTED POWERS. FINALLY, IT DEMONSTRATES THROUGH THE ANALYSIS OF BRAZILIAN SUPREME COURT'S (STF) DECISIONS AND OTHER COURTS DECISIONS SUCH AS STJ HOW BRAZILIAN JUdicIal POWER haS FACED ISSUES OF PUBLIC POLICIES IN ORDER TO ENFORCE BASIC RIGHTS PRESENT IN THE BRAZILIAN CONSTITUTION OF 1988.

\section{KEYWORDS}

CONSTITUTIONAL JURISDICTION; JUDICIALIZATION OF POLITICS; JUDICIAL REVIEW; JUDICIAL SELF-RESTRAINT; PUBLIC POLICIES.

\section{INTRODUÇÃO}

Nas últimas décadas, o Brasil e o mundo vêm experimentando a transferência de parte do poder político para os tribunais. Em certa medida, pode-se dizer que esse poder tem saído da esfera de representação parlamentar para o âmbito do Poder Judiciário.

A ideia de supremacia constitucional, que foi adotada na Constituição americana de 1787, é agora compartilhada entre vários países, especialmente após a segunda metade do século XX, quando se inicia uma preocupação mundial em torno dos direitos humanos. Estes, por sua vez, passam a influenciar o direito interno dos 
países, que passam a adotar declarações de direitos fundamentais que funcionam como parâmetros para o controle de constitucionalidade das leis e dos atos administrativos pelos tribunais.

Nos países da América Latina, do Leste Europeu e da África do Sul, a adoção do constitucionalismo se dá com a implementação de regimes democráticos após um longo período de governos ditatoriais. Um Judiciário forte aparece, assim, como garantia dos novos arranjos democráticos (Tate; Vallinder, 1995, p. 2). Aliado a isso, a adoção de Constituições democráticas e rígidas, com catálogo de direitos fundamentais supremos e protegidos contra as maiorias parlamentares, resultou em um novo modo de interpretar e aplicar o Direito. Isto, por sua vez, implicou - no caso do Brasil - um aumento da atividade do Poder Judiciário e uma preponderância desse poder nas decisões políticas do Estado brasileiro, colocando essa questão no centro do debate jurídico e político atual.

Até mesmo países com tradição de common law adotaram Cartas de Direitos Fundamentais, ${ }^{1}$ que passaram a servir de parâmetro para o controle de constitucionalidade das leis com elas incompatíveis. Dessa forma, as Cortes Constitucionais de diversos países têm sido cada vez mais demandadas a resolver litígios que envolvem desde questões relacionadas aos direitos de liberdade (liberdade de expressão, liberdade religiosa e direito à privacidade) a questões relacionadas a biodireito, aborto, políticas públicas na área de saúde, educação, meio ambiente, processo eleitoral, união homoafetiva, etc.

O crescimento da importância dos Tribunais se deu não só no sentido quantitativo, mas também no sentido de que cada vez mais estes se manifestam sobre questões políticas centrais para a sociedade, redesenhando os próprios papéis dos Poderes Executivo, Legislativo e Judiciário.

Esse fenômeno é definido como judicialização da política e pode significar tanto a transferência das decisões do campo parlamentar ou executivo para as Cortes, como o aumento dos métodos judiciais de tomada de decisões para além dos tribunais (Vallinder, 1995, p. 13).

O presente artigo buscará analisar o fenômeno da judicialização da política no Brasil, especialmente a partir da Constituição de 1988.

Em contraponto, far-se-á um paralelo com a doutrina da autorrestrição judicial, desenvolvida para limitar a atuação política do Poder Judiciário que, a seu turno, defende a deferência por parte dos Tribunais de questões políticas para que sejam enfrentadas pelos poderes eleitos.

Por fim, procurar-se-á demonstrar, por meio de análise de decisões do Supremo Tribunal Federal e do Superior Tribunal de Justiça, que o controle de constitucionalidade de questões políticas ou políticas públicas à luz da Constituição de 1988 já vem acontecendo no Brasil como meio para garantir a realização dos direitos fundamentais. 


\section{JUdicialização dA POLÍTICA}

A judicialização da política pode ser estudada sob diversos aspectos. É possível afirmar que a própria ideia de constitucionalismo e de previsão de questões políticas na Constituição permitiriam que o Judiciário acabasse enfrentando qualquer questão política como sendo uma questão constitucional. ${ }^{2}$ Apesar de ser aparentemente contra os interesses do Parlamento, é possível afirmar que há um consenso no sentido de que a assunção de novos papéis pelo Judiciário, incluindo as decisões sobre questões políticas, morais, religiosas, centrais, tanto por parte da sociedade quanto por parte dos próprios atores políticos, vem sendo aceita pela sociedade, uma vez que os próprios atores políticos veem o Judiciário como um fórum apropriado para enfrentar essas questões.

Werneck Vianna afirma que o "boom da litigação" é um fenômeno mundial que vem ocorrendo nas democracias contemporâneas, especialmente por conta da distância existente entre representantes e representados, o que, em consequência, leva os políticos a estimularem os canais de representação por via da legislação (Vianna; Burgos; Salles, 2007, p. 41).

Não obstante ser um fenômeno atual, o discurso muitas vezes confunde a ideia de judicialização da política com a ideia genérica de ativismo judicial, tanto que se tem utilizado o termo de judicialização de megapolítica (ou de macropolítica) para distingui-lo da judicialização da política genérica.

Ran Hirschl vai apresentar três categorias de judicialização: (i) a expansão do discurso legal, jargões, regras e procedimentos para a esfera política e para os fóruns de decisões políticas; (ii) judicialização das políticas públicas por meio do controle de constitucionalidade ou das revisões dos atos administrativos; (iii) judicialização da política pura ou da política macro, que seria a transferência às Cortes de questões de natureza política e de grande importância para a sociedade, incluindo questões sobre legitimidade do regime político e sobre identidade coletiva que definem (ou dividem) toda a política (Hirschl, 2006, p. 723).

Em relação à primeira categoria, o autor afirma que a judicialização é inerente à captura das relações sociais e culturais pelas leis, o que se deve ao aumento da complexidade e diversidade das modernas sociedades, bem como da expansão de Estados modernos de bem-estar social, com suas inúmeras agências regulatórias (Hirschl, 2006, p.724-725).

No âmbito supranacional também se verifica esse fenômeno, na medida em que se torna necessário adotar normas-padrão (universais) numa era de globalização econômica. Outro aspecto da judicialização da política é o aumento da responsabilidade do Judiciário em decidir sobre políticas públicas, especialmente sobre questões de direitos garantidos constitucionalmente, ${ }^{3}$ o que acaba por redefinir os próprios limites dos demais poderes políticos.

Em relação à judicialização da política pura, ou da macropolítica, pode-se entender a competência dos tribunais para decidir a respeito de questões morais ou de 
questões políticas críticas centrais para a sociedade. Ou seja, muitos dilemas morais e políticos acabam sendo transferidos das esferas políticas ao Judiciário.

Nesse sentido é possível pensar na judicialização da política como relacionada ao "novo estatuto dos direitos fundamentais e à superação do modelo de separação dos poderes do Estado, o que provoca uma ampliação dos poderes de intervenção dos tribunais na arena política" (Verbicaro, 2008, p. 391), especialmente por meio da participação nos processos de formulação ou implementação de políticas públicas, conforme se verá no último tópico do presente artigo. Na tentativa de garantir à comunidade seus direitos fundamentais elencados na Constituição Federal, a política se judicializa.

Débora Maciel e Andrei Koerner explicam que a judicialização da política "requer que operadores da lei prefiram participar da policy-making a deixá-la ao critério de políticos e administradores e, em sua dinâmica, ela própria implicaria um papel político mais positivo da decisão judicial do que aquele envolvido em uma não decisão" (Maciel; Koerner, 2002, p. 114).

No Brasil, o processo de redemocratização acabou por produzir enorme impacto no Poder Judiciário. Arantes explica que: "de um lado, a demanda por justiça, em grande parte represada nos anos de autoritarismo, inundou o Poder Judiciário com o fim dos constrangimentos impostos pelo regime militar ao seu livre funcionamento". Por outro lado, a adoção de um Estado Democrático de Direito gerou a "necessidade de juízes e árbitros legítimos" virem a decidir sobre conflitos entre sociedade e governo e entre os poderes do próprio Estado. Esse papel, segundo o autor, foi atribuído em grande medida ao Poder Judiciário (Arantes, 1999, p. 83).

Ainda, comparando o Brasil às democracias contemporâneas, Arantes entende que o mesmo passa por praticamente as mesmas causas de judicialização da política de outros países:

First, political democracy was established in the 1980s followed by the approval of a new Constitution in 1988 that set out an extensive charter of rights. Second, an increasingly greater number of interest groups within society are demanding judicial solutions to collective conflicts. Third, the political system is characterized by fragile and even minority coalitions supporting the government of the day, while the opposition uses the judiciary to fight government policies. Lastly, the constitutional model delegates to the judiciary and to the Ministério Público (Public Ministry) the task of protecting both individual rights and interests, as well as collective and social rights (Arantes, 2006, p. 231).

Loiane Prado Verbicaro aponta algumas condições como facilitadoras do processo de judicialização da política ocorrido no Brasil, dentre as quais, destacam-se especialmente: (i) a promulgação da Constituição de 1988; (ii) a universalização do acesso à 
justiça; (iii) a existência de uma Constituição com textura aberta; (iv) a decodificação do direito, a crise do formalismo e do positivismo jurídico; (v) a ampliação do espaço reservado ao STF; (vi) a hipertrofia legislativa; e (vii) a crise do Parlamento brasileiro (Verbicaro, 2008, p. 390).

Veja-se que a abertura das normas de direitos fundamentais exigem um novo papel do Poder Judiciário, um papel que se assemelha ao que esse Poder tem nos sistemas de tradição do common law, no qual é através do seu papel criador, de judge-made-law, que se densifica e se concretiza as normas previstas na Constituição.

O caráter aberto e abstrato das normas constitucionais modifica o paradigma positivista de uma suposta previsão da norma a ser adotada ao caso concreto, passando os países que adotaram o constitucionalismo como forma de proteção dos direitos fundamentais contra as arbitrariedades estatais a se aproximar do common law, especialmente no que diz respeito à jurisdição constitucional.

Como não há possibilidade de se apontar previamente qual o direito aplicado ao caso, caberá ao Judiciário densificar e dar significado a esses direitos, de acordo com o contexto histórico, social, político, moral e jurídico da sociedade naquele determinado momento. A norma, portanto, não existe no texto, mas apenas no caso concreto.

Esse novo papel dos Tribunais Constitucionais, especialmente com a possibilidade de dar conteúdo aos direitos humanos, reflete em grande expansão de sua autoridade, o que se dará por meio do judicial review.

Além disso, é possível constatar-se que, no Brasil, a Justiça se aproximou da população por meio de Juizados de Pequenas Causas, nos quais o acesso independe de representação por advogado. Legislações especiais de proteção de minorias, como Código de Defesa do Consumidor, Estatuto da Criança e do Adolescente, Estatuto do Idoso, Lei Maria da Penha, ${ }^{4}$ levaram a um processo de substituição do Estado pelo Judiciário, tornando o juiz protagonista nas decisões sobre questões sociais, inclusive as que envolvem políticas públicas (Vianna; Burgos; Salles, 2007, p. 41).

Aliado a isso, o sistema de controle de constitucionalidade misto tem no controle difuso a possibilidade de minorias políticas exercitarem seu poder de veto contra leis e atos administrativos editados pelos Poderes Legislativo e Executivo, invocando a Constituição de 1988, podendo-se afirmar que o controle de constitucionalidade é um dos maiores recursos disponíveis para as minorias políticas contra as decisões políticas majoritárias (Arantes, 2006, p. 241). Em sentido contrário, Antonio Moreira Maués e Anelice Belém Leitão (2004, p. 48), ao analisarem as ADIs dos Partidos Políticos no Supremo Tribunal Federal, concluem que estas "são mais bem interpretadas como ações em defesa da Constituição" do que efetivamente tentativas de desrespeito à regra da maioria, ou seja, levam à Jurisdição Constitucional a possibilidade de limitar possíveis violações da Constituição cometidas pela maioria política. 
Tal afirmativa encontra respaldo em Ernani Rodrigues de Carvalho (2004), ao constatar que "os grupos de interesse passam a considerar e/ou utilizar a possibilidade de veto dos tribunais na realização de seus objetivos”.

Por outro lado, pode-se verificar decisões do Supremo Tribunal Federal sobre questões políticas no que diz respeito à fidelização partidária, políticas públicas de saúde, desarmamento, pesquisa em células-tronco, mensalão, etc. ${ }^{5}$ Algumas dessas questões chegaram ao Supremo por meio de ações perpetradas por partidos políticos e outras por associações representativas de direitos de minorias, além daquelas que foram impetradas individualmente para garantia de direitos sociais.

Esse aumento de deferência do Legislativo para o Judiciário aconteceu em várias nações ao redor do mundo, transformando as Supremas Cortes no mais importante corpo de tomada de decisão política. ${ }^{6}$

Em decorrência desse movimento, o Judiciário brasileiro tem sofrido severas críticas, assim como sofreu a Suprema Corte americana no início do século XX, no sentido de que não é órgão competente para tratar de questões políticas por não ser eleito pelo povo e, portanto, não teria legitimidade democrática para manifestar-se sobre tais questões.

Muito embora este artigo adote como pressuposto a legitimidade democrática do judicial review, deve ser colocado que não se desconhece as críticas que vêm sendo feitas a esse instituto. No tocante a essas críticas, merece destaque a posição de Jeremy Waldron. Uma das preocupações centrais desse autor é combater a ideia, bastante difundida, de que o procedimento legislativo pode dar origem à tirania da maioria e que essa maioria, constantemente, viola ou constrange o exercício de direitos individuais ou das minorias - e daí se originaria a necessidade de determinados limites ao procedimento democrático majoritário (Waldron, 1999a, p. 11). Considerando que os membros de uma comunidade política entram em desacordo não somente em relação aos direitos e seus conteúdos, mas também em relação a questões de justiça social e políticas públicas, seria razoável concluir que a própria concepção das minorias quanto aos seus direitos (ou violação destes) pode gerar desacordo. Outrossim, do fato de que esses direitos podem ser violados pela maioria não decorre, necessariamente, que a única maneira de evitar que isso aconteça seja controlando a vontade da maioria por meio do judicial review.

No ensaio The Core of the Case Against Judicial Review, Waldron (2006, p. 1346) enuncia que a crítica ao judicial review pode ser levada a efeito mediante dois argumentos centrais: (i) não existe nenhuma razão para supor que os direitos estariam melhor protegidos pelo exercício do judicial review do que por legislaturas democráticas; e (ii) não obstante os resultados que o judicial review possa gerar, sob o ponto de vista da democracia ele é ilegítimo. A análise que o autor faz desse problema não está centrada em decisões particulares obtidas dentro de um sistema político e também não se prende ao contexto histórico que dá origem ao instituto, sua intenção foi 
formular uma crítica geral ao instituto. O que ele pretende identificar como argumento central da sua crítica ao judicial review "é que ele é independente de suas manifestações históricas e questões sobre seus efeitos particulares - as decisões (boas ou más) que ele tenha formulado, as deficiências ou afirmações que ele tenha transmitido" (Waldron, 2006, p. 1346-1351).

Em que pesem essas críticas ao "governo de juízes", é fato o protagonismo do Judiciário, sendo essas críticas "insuficientes para reprimir um processo que parece ter se tornado irreversível" (Chevallier, 2009, p. 134).

Esse protagonismo do Judiciário é muitas vezes chamado de ativismo judicial, o qual deve ser entendido não quanto uma Corte é ocupada mas quanto seus juízes estão dispostos a desenvolver o direito. As críticas e a controvérsia a respeito do ativismo judicial se dão especialmente por duas razões. A primeira diz respeito ao caráter contramajoritário dos juízes, que não teriam competência para elaborar novo direito, pois não foram eleitos pelo povo. A segunda questão é, em se aceitando que os juízes podem desenvolver a lei, quais seriam os critérios para definir que o desenvolvimento seria adequado (Dickson, 2007, p. 367). ${ }^{7}$

Christopher Wolfe traz outra concepção do que ele chama de ativismo judicial convencional, como sendo aquele em que os juízes devem decidir os casos que lhes são apresentados e não evitá-los, de modo a realizar a justiça, especialmente protegendo a dignidade da pessoa humana pela expansão da igualdade e da liberdade. Os juízes "ativistas" devem se comprometer a garantir soluções para os problemas sociais, principalmente utilizando-se de seu poder para dar conteúdo aos direitos e às garantias fundamentais que venham a realizar a justiça social (Wolfe, 1997, p. 2). ${ }^{8}$ Ativistas não no sentido pragmático de ignorar a Constituição ou os precedentes que lhe interpretaram, para impor seu próprio ponto de vista, mas no sentido de que devem estar eles preparados para responder às questões de moralidade política que lhe são apresentadas.

Como se viu até aqui, é difícil encontrar uma única causa para justificar a judicialização da política. Não obstante, é certo que muitas das questões políticas que são transferidas para os Tribunais o são por partidos políticos ou por grupos de interesses e, portanto, isso não pode ser visto como um fenômeno jurídico ou como um fenômeno de usurpação de funções de um poder sobre o outro, mas como um fenômeno político.

O que se verifica é que o Poder Judiciário tem sido utilizado como outra arena política, em que as minorias políticas no âmbito de discussão deliberativa parlamentar têm a possibilidade de ter protegidos seus direitos.

Mesmo no contexto americano, Keith Whittington explica que a manutenção da autoridade judicial para interpretar a Constituição e usar ativamente o poder de controle constitucional das leis é um projeto político avançado. Para que se sustente o ativismo judicial, no sentido de declaração de inconstitucionalidade do ato normativo do Legislativo ou do Executivo, as Cortes devem operar numa política de desenvolvimento favorável. Juízes devem achar razões que levantem objeções aos 
atos do governo, e políticos eleitos devem achar razões para parar de sancionar ou criticar juízes que levantam tais objeções (Whittington, 2005, p. 583).

Whittington (2005, p. 584) ressalta que as maiorias políticas podem efetivamente delegar um número de questões para o Judiciário porque as Cortes podem ter mais capacidade de agir efetivamente ou com mais confiança do que os políticos eleito, agindo diretamente. Tal ponto de vista é corroborado por Luiz Werneck Vianna, quando afirma que as ADIs no governo Fernando Henrique Cardoso (FHC) acabaram por funcionar em instrumentos em favor das minorias políticas, que buscaram no Judiciário um outro espaço de luta democrática para afirmar direitos que não conseguiram proteção majoritária no Parlamento (Vianna; Burgos; Salles, 2007, p. 68). Ou seja, o Poder Judiciário assume, nesse contexto, um importante papel, na medida em que representa um espaço público democrático realizador dos direitos fundamentais protegidos na Constituição brasileira.

No mesmo sentido, afirma Howard Gillman (2002, p. 511), ao estudar o período de 1875 a 1891 nos Estados Unidos, que o aumento do poder da jurisdição das Cortes federais durante esse período foi devido a esforços do Partido Republicano de promover uma política econômica nacional, durante um período no qual o tema estava vulnerável em relação aos partidos políticos.

O exercício do controle de constitucionalidade por um Judiciário ativo e independente, apesar de ser visto aparentemente como contra o interesse dos atuais políticos, que presumivelmente preferem exercer o poder sem interferência é, ao contrário, apoiado pelos detentores do poder. Quando políticos eleitos não conseguem implementar sua própria agenda política, eles devem favorecer um ativo controle de constitucionalidade por um Judiciário simpático a superar os obstáculos e romper com o statu quo. Na visão de Whittington (2005, p. 583), isso justificaria o porquê de os políticos eleitos toleram um Judiciário ativista. ${ }^{9}$

No Brasil, ao fazer um aprofundado estudo acerca da judicialização da política no país, Werneck Vianna ressalta que, além das ADIs funcionarem como instrumento de defesa das minorias, também funcionam como um recurso institucional estratégico de governo (Vianna et al., 2007, p. 44). Das ADIs propostas no período de 1988 a 2005, 60\% trataram do tema de Administração Pública, 12,6\% trataram sobre Política Tributária, e 11,6\% trataram sobre Regulação da Sociedade Civil (Vianna et al., 2007, p. 50).

Por outro lado, verificou-se que das ADIs propostas por governadores, 87,1\% foram propostas contra leis estaduais, demonstrando que os governos, quando não ganham na arena política, buscam o Judiciário para garantir suas pretensões (Vianna et al., 2007, p. 54).

O alto índice de litigação contra normas dos Legislativos estaduais se justifica, segundo o autor, porque reflete que o Executivo não detém maioria nas assembleias estaduais, bem como porque "essas instâncias de poder, expostas às pressões de grupos 
de interesses particularistas, eventualmente produzem uma legislação casuística e sem escopo universalista" (Vianna et al., 2007, p. 50), acabando o STF por desempenhar o papel de um conselho de Estado.

Por meio de dados estatísticos concretos, o autor demonstra que as ADIs têm sido utilizadas como instrumento de afirmação de interesses minoritários, tanto que as ADIns propostas por partidos políticos, no período do governo FHC em sua maioria foram propostas por partidos de esquerda, tendo caído a atuação desses partidos significativamente após o governo Lula. A análise das ADIs, segundo Vianna, "aponta o fato de elas se afirmarem como uma via complementar de disputa política e de exercício da oposição, mais utilizada pela esquerda, mas igualmente mobilizada pelo centro e pela direita" (Vianna et al., 2007, p. 67- 69).

Veja-se, ainda, que questões políticas importantes como a fidelização partidária foram remetidas ao STF justamente pelos Partidos Políticos (PPS, PSDB e DEM), ${ }^{10}$ o que demonstra, mais uma vez, que a judicialização da política com a consequente manifestação do Supremo Tribunal Federal sobre questões políticas se faz por vontade dos próprios partidos políticos e, portanto, como um fenômeno político. ${ }^{11}$

$\mathrm{O}$ que se percebe nesse novo contexto político-jurídico criado no pós-guerra com o estabelecimento da supremacia dos direitos humanos, seja por constituições escritas ou não, é que esse movimento se dá junto com a expansão do judicial review em diversos países.

Essa expansão amplia o espaço público de debate sobre questões morais e políticas na sociedade, que ganha uma nova arena, o Poder Judiciário, o qual assume papel protagonista na concretização dos direitos fundamentais previstos na Constituição.

Verifica-se, ainda, que a atuação do Judiciário é legítima, na medida em que, provocada por atores políticos, também legitima o próprio documento constitucional.

O grande desafio está em superar as barreiras colocadas à atuação do Judiciário pela tradição do civil law, que pretendia limitar a atuação do juiz no texto normativo. A revolução dos direitos humanos e a judicialização da política expandem a atividade judicial não só no sentido quantitativo, mas também porque assume esse poder o papel de concretizar direitos que só terão significado no caso concreto, o que os aproxima do papel do judge-made-law presente nos sistemas de tradição do common law.

Verificar-se-á no próximo tópico a teoria da autorrestrição judicial, que busca limitar o papel do Judiciário na tomada de decisões que envolvem questões políticas.

\section{TEORIA DA AUTORRESTRIÇÃO JUDICIAL}

A doutrina que se preocupa em limitar o papel e as funções da jurisdição constitucional, por entender que o exercício do judicial review "importa sempre em uma afronta à vontade da maioria, representada pelo Parlamento” (Mello, 2004, p. 205), é conhecida como doutrina da self-restraint ou doutrina da autocontenção judicial. 
Conforme Canotilho (2000, p. 1224), o princípio da autolimitação judicial consiste no fato de que "os juízes devem autolimitar-se à decisão de questões jurisdicionais e negar a justiciabilidade das questões políticas”, o que significaria dizer que certas questões políticas não estariam sujeitas a um controle jurisdicional.

Numa concepção procedimental de Constituição, deve-se ter confiança na legitimidade ética dos procedimentos discursivos de deliberação e decisão de questões públicas, o que justificaria a limitação da jurisdição constitucional sobre os assuntos deliberados. Ou seja, numa concepção procedimental, a jurisdição constitucional deve estar limitada a proteger os direitos de participação política que garantam a higidez do processo democrático.

O problema que se enfrenta é a definição de quais direitos fundamentais, que protegem o processo democrático, poderiam ser tutelados pela jurisdição constitucional, o que abriria um rol maior de direitos que serão objeto de proteção e de valoração substantiva pelo Judiciário.

Por outro lado, a concepção substantiva ${ }^{12}$ de Constituição não defende uma autolimitação judicial mas, ao contrário, defende um ativismo judicial que determine e proteja os valores substantivos calcados na Constituição, principalmente no que diz respeito aos direitos fundamentais.

Cláudio Ari Mello constata que existem vários métodos de autorrestrição judicial: (i) os limites processuais, por meio de "instituição de barreiras formais nos processos judiciais da jurisdição constitucional” (2004, p. 218); (ii) os limites hermenêuticos, em que prevalece o princípio da presunção de constitucionalidade das leis, "sempre que for possível reconhecer nela uma compreensão adequada ao sentido normativo da constituição" (2004, p. 220); (iii) os limites funcionais que se desdobram em discricionariedade administrativa e discricionariedade legislativa ou liberdade de conformação do legislador; e (iv) os limites temáticos, consistentes na doutrina da não justiciabilidade das questões políticas.

Christopher Wolfe (1994, p. 101ss), de forma clara, aponta que os limites para um judicial review moderado seriam os seguintes: (i) os limites inerentes ao Poder Judiciário; (ii) a deferência legislativa; e (iii) a doutrina das questões políticas.

Wolfe cita que um dos limites inerentes à natureza do Poder Judiciário é o fato de que o judicial review deveria ser visto mais como um problema de interpretação (associado a julgamento por Hamilton) do que legislação (associada à intenção). O papel dos juízes não seria determinar o que é melhor para o país, ou qual regra geral é melhor para a nação e para seus cidadãos, quando se depara com um problema específico de política. Esse autor também entende não ser tarefa do juiz valorar se uma lei é prudente ou justa. No exercício do judicial review, caberia ao juiz determinar não se a lei é boa ou prudente, mas se é constitucional ou não (Wolfe, 1994, p. 101).

Outro limite natural ao Poder Judiciário consiste no fato de que suas decisões só 
produzem eficácia no caso concreto, diferente das leis que são pensadas e aplicadas para toda a sociedade (Wolfe, 1994, p. 102). ${ }^{13}$

Wolfe (1994, p. 103) destaca, também, a diferença feita por Marshall em Marbury v. Madison entre atos judiciais e atos não judiciais, isto é, a questão sobre se alguém tem um direito é, por sua natureza, uma questão judicial, e deve ser tratada pela autoridade judicial. Não obstante, Marshall reprovava a interferência do Judiciário em atos políticos ou discricionários do Poder Executivo. ${ }^{14}$

Afora isso, Wolfe (1994, p. 103-104) salienta que o judicial review é um poder derivado do poder de decidir casos que chegam ao Judiciário, podendo uma questão constitucional nunca chegar ao Judiciário e, portanto, nunca ser apreciada por este Poder.

Por outro lado, a defesa clássica do judicial review sempre foi fundamentada no fato de que o mesmo não implicaria na superioridade dos juízes em relação aos legisladores, mas na superioridade do desejo do povo - plasmado na Constituição - sobre ambos. Entretanto, essa afirmativa só é verdadeira se o judicial review se restringir à interpretação ou à determinação da intenção do povo prevista na Constituição, não podendo o juiz legislar ou defender seus próprios anseios.

Se houver erro na declaração de inconstitucionalidade de uma lei, poder-se-ia ter o Judiciário legislando, eis que, mesmo de boa-fé, estaria a extrapolar os poderes do judicial review, razão por que o princípio da deferência ao legislativo significa que o judicial review não deve ser utilizado em caso de dúvidas.

Em caso de dúvidas sobre a própria interpretação da Constituição, os juízes deveriam submeter a questão ao Legislativo, para que este emita sua opinião sobre a constitucionalidade da lei (Wolfe, 1994, p. 104). Mas não é qualquer dúvida que ensejaria essa deferência legislativa, sendo necessário se estar frente a uma dúvida que persiste mesmo após certo esforço interpretativo de tentar compatibilizar a lei à Constituição. ${ }^{15}$

Ressalte-se que nenhum dos autores que defende a autocontenção judicial enfrenta como isso seria feito na prática, nem se seria viável, por exemplo, suspender o julgamento judicial e submeter a questão ao Legislativo (tal como um incidente "substantivo"), para se decidir a respeito do conteúdo substantivo constitucional, ou quem sabe submeter a questão a um plebiscito. Não se traz como esse tipo de autocontenção pode se realizar na prática.

Outro componente, segundo Christopher Wolfe (1994, p. 106), de um judicial review moderado, consistiria na doutrina das questões políticas. Desde que a revisão judicial seja um poder estritamente judicial, não deveria ser aplicada para rever atos discricionários de outros poderes, sendo, portanto, uma decorrência lógica do princípio da separação de poderes.

No que diz respeito à discricionariedade legislativa ou liberdade de conformação do legislador, e mesmo na questão de não justiciabilidade de questões 
políticas, em alguns casos, a Suprema Corte americana opta por não se manifestar sobre o assunto.

Quando se trata do princípio federativo há, em geral, uma deferência à manifestação pelos Estados. Do mesmo modo, a Suprema Corte tem tido permanentemente "uma orientação no sentido de prestar grande deferência às decisões tomadas pelo presidente ou pelo Congresso, quando estão em jogo problemas de segurança, ou às orientações das organizações militares” (Baracho Júnior, 2003, p. 329-330).

Ainda, sobre a matéria de homossexuais nas Forças Armadas, "a Suprema Corte se recusa a apreciar a política denominada do not ask, do not tell, presente nas organizações militares norte-americanas" (Baracho Júnior, 2003, p. 330), sustentando que os homossexuais não são considerados uma minoria isolada e prejudicada e demonstrando, assim, a ampla deferência às decisões militares.

Não obstante, a própria história do judicial review demonstra que a doutrina do judicial self-restraint não se solidificou, posto a história demonstrar uma verdadeira expansão dos poderes do Judiciário, inclusive em matérias de políticas públicas e sociais, como visto na sessão anterior.

Ratificando o supraexposto, Canotilho entende que "a doutrina das questões políticas" ou da não justiciabilidade das questões políticas não pode significar a existência de questões constitucionais isentas de controle, não devendo o Tribunal Constitucional recusar a apreciação de uma matéria ou declinar de sua competência apenas por se tratar de questão política. Afirma, ainda, que o problema não consiste em fazer política por meio do controle de constitucionalidade das leis, mas em apreciar a constitucionalidade da política, o que deve ser feito por meio de parâmetros jurídico-materiais presentes na própria Constituição (Canotilho, 2000, p. 1224).

Uma posição interessante de limites ao controle de questões políticas por parte do Judiciário é afirmada pela doutrina argentina e pela Suprema Corte desse país, no sentido de que os Tribunais não podem se manifestar sobre matérias que são naturalmente privativas dos outros poderes. Deve-se verificar a repartição de competências estabelecidas na Constituição, não se admitindo que o Judiciário controle questões relativas a matérias exclusivas ou privativas de outros poderes (Haro, 2008).

Não obstante tal posicionamento dos defensores de uma autolimitação do Judiciário, entendeu a Suprema Corte da Argentina que é tarefa dos Tribunais interpretar o alcance das normas que concedem competências, bem como verificar se os poderes agiram nos limites de sua competência. ${ }^{16}$

Haro apresenta crítica a essa doutrina, que também buscaria a autorrestrição do Judiciário, no sentido de que seria um absurdo pensar que faculdades privativas seriam o mesmo que competências não passíveis de revisão judicial. Ou seja, ter-seia que aceitar que matérias relacionadas à competência privativa, como aprovação de lei pelo Congresso ou veto de projeto de lei pelo presidente ou, ainda, a edição de medida provisória pelo presidente, estariam fora do controle de revisão do Poder 
Judiciário, mesmo quando fossem abertamente violadores da ordem constitucional ou legal (Haro, 2008).

No Brasil, em geral, encontra-se uma "resistência ao controle judicial do mérito dos atos do Poder Público, aos quais se reserva um amplo espaço de atuação autônoma, discricionária” (Krell, 2002, p. 87), que não se sujeitam ao controle de constitucionalidade pelo Judiciário. Como exemplo de atitudes exageradas de autorrestrição judicial tem-se a recusa do Supremo Tribunal Federal em "controlar os pressupostos constitucionais da edição de Medidas Provisórias pelo Governo Federal (art. 62, CF)", bem como a negativa de criar norma in concreto nos casos de mandado de injunção (Krell, 2002, p. 87-88).

Não obstante os casos supramencionados, é possível afirmar que cada vez mais o Judiciário brasileiro tem assumido a tomada de decisões políticas em questões centrais para a sociedade. E mais, a teoria da autorrestrição judicial é difícil de ser implantada também porque, muitas vezes, os próprios atores políticos preferem que as decisões políticas sejam tomadas pelos tribunais. Ou seja, os tribunais ou cortes constitucionais acabam funcionando como trunfos para minorias políticas que não conseguem aprovação dos seus objetivos na arena política (Whittington, 2005, p. 583). ${ }^{17}$

Passa-se, agora, a analisar de que forma o Judiciário brasileiro, especialmente o Supremo Tribunal Federal e o Superior Tribunal de Justiça, vem funcionando como um aliado da política, em particular das minorias políticas, no controle de constitucionalidade das políticas públicas.

\section{Controle judicial de políticas públicas}

Para enfrentar a justiciabilidade de políticas públicas, é necessário analisar previamente a justiciabilidade das questões políticas. A doutrina vem tentando definir o que são questões políticas, muitas vezes chegando a definições redundantes, como sendo questões políticas aquelas que não são jurídicas ou que não são judiciais. Em alguns casos, os estudiosos acabam aceitando que questão política é aquela que os juízes dizem que é.

Ronald Dworkin é um dos poucos juristas que tenta definir o que são questões políticas, diferenciando-as de princípios, no sentido de que caberia aos Tribunais apenas decisões baseadas em princípios:

Los argumentos políticos justifican una decisión política demostrando que favorece o protege alguna meta colectiva de la comunidad en cuanto todo. El argumento en favor de un subsidio para los fabricantes de aviones, que afirma que con él se protegerá la defensa nacional, es un argumento político. Los argumentos de principio justifican una decisión política demostrando que tal decisión respeta o asegura algún derecho, individual o del grupo. El argumento a favor de las leyes que se oponen a la discriminación (racial en los Estados Unidos), y que sostiene que una 
minoría tiene derecho a igual consideración y respeto, es un argumento de principio (Dworkin, 2002, p. 148).

Dessa definição poder-se-ia deduzir que o conceito de política pública (policy) diz respeito a metas coletivas, objetivos sociais que demandam programas de ação pelos Poderes Públicos, comum num Estado que se pretende social. Já os princípios estariam mais relacionados a proteções de direitos individuais.

Pode-se, então, relacionar as políticas públicas aos programas de ações governamentais que buscam a realização de metas coletivas como um todo, especialmente na área social (pleno emprego, saúde pública, moradia, etc.).

Fabio Konder Comparato, por sua vez, esquadrinhando o que seja política, parte de uma constatação negativa, ou seja, política "não é uma norma nem um ato, ela se distingue nitidamente dos elementos da realidade jurídica, sobre os quais os juristas desenvolveram a maior parte de suas reflexões, desde os primórdios da iurisprudentia romana" (Comparato, 1998, p. 44). O autor ressalta a importância dessa constatação, uma vez que, originariamente, o controle de constitucionalidade se dá apenas em relação a atos e normas, e classifica a política como uma atividade, ou seja, "um conjunto organizado de normas e atos tendentes à realização de um objetivo determinado" (Comparato, 1998, p. 44).

Maria Paula Dallari Bucci, por sua vez, elabora a seguinte definição para política pública:

Política pública é o programa de ação governamental que resulta de um processo ou conjunto de processos juridicamente regulados - processo eleitoral, processo de planejamento, processo de governo, processo orçamentário, processo legislativo, processo administrativo, processo judicial - visando coordenar os meios à disposição do Estado e as atividades privadas, para a realização de objetivos socialmente relevantes e politicamente determinados.

Como tipo ideal, a política pública deve visar a realização de objetivos definidos, expressando a seleção de prioridades, a reserva de meios necessários à sua consecução e o intervalo de tempo em que se espera o atingimento dos resultados (Bucci, 2006, p. 39).

Também não se pode descurar que é por meio de políticas públicas coletivas que a Constituição brasileira pretende que sejam realizados e garantidos os direitos fundamentais sociais. Por óbvio, são direitos que dizem respeito a toda a sociedade, considerada em sua forma coletiva e não apenas de garantias de direitos individuais, e por isso a necessidade de políticas macro para sua realização, dando-se conta das necessidades do povo, bem como da capacidade do Estado. 
Rodolfo de Camargo Mancuso, por sua vez, define política pública como sendo uma "conduta comissiva ou omissiva da Administração Pública, em sentido largo, voltada à consecução de programa ou meta previsto em norma constitucional ou legal, sujeitando-se ao controle jurisdicional amplo e EXAURIENTE, especialmente no tocante à eficiência dos meios empregados e à avaliação dos resultados alcançados” (Mancuso, 2001, p. 730-731).

Entretanto, o que se tem observado é que, a despeito da ausência de recursos orçamentários suficientes, o Estado estaria desobrigado de realizar e planejar políticas públicas para garantia dos direitos fundamentais sociais. E também que tal questão não poderia ser submetida ao controle de constitucionalidade pelo Poder Judiciário, pois tratar-se-ia de questão política, reservada aos poderes eleitos pelo povo, e ainda, sob pena de violação ao princípio da separação de poderes.

Explica-se: o princípio da "reserva do possível" vem funcionando como um óbice à legitimação do Judiciário na realização dos direitos fundamentais sociais, negando, alguns autores, "de maneira categórica a competência dos juízes ("não legitimados pelo voto') a dispor sobre medidas de 'políticas sociais que exigem gastos orçamentários'” (Krell, 2002, p. 52). Ou seja, quando se trata da realização dos direitos fundamentais sociais pelo Judiciário, o mesmo tem questionada sua legitimidade democrática uma vez que "a concretização de direitos sociais implicaria a tomada de opções políticas em cenários de escassez de recursos" (Souza Neto, 2003, p. 44), o que levaria à conclusão de que a tomada de políticas públicas não poderia ser feita por um poder não eleito, mas tão somente pelo Executivo e Legislativo que, por sua vez, refletiriam a vontade da maioria.

Não perdendo de vista a disparidade social presente no Brasil, onde a grande maioria dos direitos sociais está longe de ser usufruída pela população, deve-se questionar quem, então, tem legitimidade para “definir o que seja 'o possível' na área das prestações sociais básicas, em face da composição distorcida dos orçamentos dos diferentes entes federativos" (Krell, 2002, p. 53), principalmente quando os recursos não foram corretamente destinados.

Ora, a partir do momento em que a Constituição estabelece que as políticas públicas são os instrumentos adequados de realização dos direitos fundamentais, por certo que se trata de matéria constitucional sujeita ao controle do Judiciário. Pensar o contrário seria o mesmo que o retorno ao pensamento de que a Constituição é apenas um documento político desprovido de normatividade, algo inaceitável num Estado que se pretende Constitucional e Democrático de Direito.

Primeiro, deve-se ressaltar que não se está a defender que o Judiciário intervenha em políticas públicas orçamentárias para a realização dos direitos sociais. É certo que cabe aos poderes Executivo e Legislativo dispor sobre políticas públicas. O que se defende é que - na inércia desses poderes -, é legítimo que o Judiciário atue quando chamado, principalmente quando se tratar de controle difuso, em que os próprios destinatários dos direitos vão reivindicar que os mesmos sejam realizados. 
Veja-se, a respeito, a posição de Cláudio Pereira de Souza Neto:

A questão central é a seguinte: se considerarmos que certos direitos sociais são condições procedimentais da democracia - como fazem, p.ex., Habermas, Gutmann e Thompson -, então o Judiciário, como seu guardião, possui também o dever de concretizá-los, sobretudo quanto tem lugar a inércia dos demais ramos do estado na realização dessa tarefa. Note-se bem: se o Poder Judiciário tem legitimidade para invalidar normas produzidas pelo Poder Legislativo, mais facilmente pode se afirmar que é igualmente legítimo para agir diante da inércia dos demais poderes, quando essa inércia implicar um óbice ao funcionamento regular da vida democrática. Vale dizer: a concretização judicial de direitos sociais fundamentais, independentemente de mediação legislativa, é um minus em relação ao controle de constitucionalidade (Souza Neto, 2003, p. 45).

Além disso, para que se tenha um eficaz controle de pesos e contrapesos dos poderes Executivo e Legislativo, é necessário também um crescimento dos papéis do Poder Judiciário. Se mantido o princípio da estrita separação de poderes, podese ter - ou manter - um Judiciário “perigosamente débil e confinado, em essência, aos conflitos privados” (Cappelletti, 1999, p. 53). Para Cappelletti, o ideal de rígida separação de poderes acaba por levar "a existência de um legislativo totalmente não controlado, como de um executivo também praticamente não controlado" (1999, p. 53). ${ }^{18}$ Isto, por sua vez, significou períodos de perigo na história mundial, nos quais "o poder era concentrado nas assembleias legislativas e grupos políticos que as dominavam” (Cappelletti, 1999, p. 53), como ocorrido na Itália pré-fascista ou na Alemanha de Weimar.

Do mesmo modo, é preciso trazer aqui as palavras de José Reinaldo de Lima Lopes quando afirma que é necessário compreender que o Estado democrático garante direitos sociais mínimos, mas também garante reformas sociais, como “condição de possibilidade e de eficácia do Estado de Direito", de modo que "não se abra um fosso insuperável de vantagens e oportunidades distintas: são estas condições de miséria que desestabilizam as democracias" (Lopes, 1994, p. 263). Assim, cabe ao Judiciário não só garantir o statu quo, protegendo o direito adquirido, como promover as reformas sociais ao implementar as normas de direitos fundamentais relacionadas à proteção do consumidor, defesa do meio ambiente, direito à saúde, etc.

Por outro lado, deve-se rechaçar "o condicionamento da realização de direitos econômicos, sociais e culturais à existência de 'caixas cheios' do Estado” (Krell, 2002, p. 54), uma vez que isso significaria reduzir a eficácia desses direitos a zero (Baracho Júnior, 2003, p. 343). ${ }^{19}$ 
É verdade que nem todos os direitos sociais têm a mesma densidade normativa. Veja-se, por exemplo, o direito ao pleno emprego ou o direito à moradia, os quais devem ser realizados por meio de políticas públicas. Isso, por sua vez, acaba por dificultar a concretização daqueles direitos pelo Poder Judiciário, pois mesmo nos países mais desenvolvidos não se pode assegurar que todo cidadão tenha emprego, pois é inevitável a existência de um certo nível de desemprego (Sunstein, 2004, p. 210).

Destarte, apesar de ser efetivamente um problema de política pública a alocação de recursos para determinados projetos que buscam a implementação de direitos sociais, isso não significa dizer que o Judiciário não tem nenhum papel na realização desses direitos. Veja-se, por exemplo, o direito à saúde e à educação: eles possuem perspectivas que permitem sua adequada realização, razão porque "a prestação concreta de serviços públicos precários e insuficientes, por parte dos municípios, dos estados e da União, deveria ser compelida e corrigida por parte dos tribunais" (Krell, 2002, p. 56).

Também é interessante mencionar duas decisões da Corte Constitucional SulAfricana a respeito da posição tomada pelo Judiciário na realização dos direitos fundamentais sociais. Aquelas demonstram que, mesmo com recursos escassos, é possível a maximização desses direitos. Ou seja, "a Corte não disse que cada pessoa na África do Sul tinha um direito individual a abrigo decente ou a tratamentos de saúde”, mas afirmou que o governo é obrigado a levar os dois direitos a sério e a adotar programas que buscam assegurá-los (Sunstein, 2004, p. 211-212).

Assim, a Corte Constitucional Sul-africana assumiu que o Judiciário pode e deve proteger os direitos econômicos e sociais e, por sua vez, definiu que cabe ao governo promover políticas para proteção desses direitos. Ou seja, não reconheceu o direito individual à moradia ou à saúde, mas reconheceu o direito dos autores de terse medidas legislativas e executivas necessárias para se alcançar a progressiva realização desses direitos.

Em outras palavras, para a Corte Constitucional Sul-africana a Constituição não criou um direito a abrigo ou moradia imediata à ação, mas criou um direito a um coerente e coordenado programa designado para cumprir obrigações constitucionais. A obrigação do Estado seria então de criar um programa que incluísse medidas razoáveis especificamente designadas para garantir algum direito a moradia (Sunstein, 2006).

No Brasil, podemos trazer como exemplo de controle de políticas públicas por parte do Judiciário a decisão tomada na ADPF 45, na qual o Supremo Tribunal Federal foi provocado a manifestar-se sobre cumprimento de políticas públicas. No caso em tela, a ação versou sobre a inconstitucionalidade do veto do Presidente da República sobre o $\S 2^{\circ}$ do art. 55 do Projeto de Lei que se converteu na Lei 10707/2003 - Lei de Diretrizes Orçamentárias -, que violaria a Emenda Constitucional 29/2000 (que estabelece recursos financeiros mínimos para o financiamento das ações e serviços da saúde). 
Veja-se a ementa da decisão:

ARGUIÇÃO DE DESCUMPRIMENTO DE PRECEITO FUNDAMENTAL. A QUESTÃO DA LEGITIMIDADE CONSTITUCIONAL DO CONTROLE E DA INTERVENÇÃO DO PODER JUDICIÁRIO EM TEMA DE IMPLEMENTAÇÃO DE POLÍTICAS PÚBLICAS, QUANDO CONFIGURADA HIPÓTESE DE ABUSIVIDADE GOVERNAMENTAL. DIMENSÃO POLÍTICA DA JURISDIÇÃO CONSTITUCIONAL ATRIBUIIDA AO SUPREMO TRIBUNAL FEDERAL. INOPONIBILIDADE DO ARBÍTRIO ESTATAL À EFETIVAÇÃO DOS DIREITOS SOCIAIS, ECONÔMICOS E CULTURAIS. CARÁTER RELATIVO DA LIBERDADE DE CONFORMAÇÃO DO LEGISLADOR. CONSIDERAÇÕES EMTORNO DA CLÁUSULA DA “RESERVA DO POSSÍVEL”. NECESSIDADE DE PRESERVAÇÃO, EM FAVOR DOS INDIVÍDUOS, DA INTEGRIDADE E DA INTANGIBILIDADE DO NÚCLEO CONSUBSTANCIADOR DO "MÍNIMO EXISTENCIAL”. VIABILIDADE INSTRUMENTAL DA ARGUIÇÃO DE DESCUMPRIMENTO NO PROCESSO DE CONCRETIZAÇÃO DAS LIBERDADES POSITIVAS (DIREITOS CONSTITUCIONAIS DE SEGUNDA GERAÇÃO) (STF, ADPF 45, Rel. Ministro Celso de Mello, DJ de 29.04.2004).

No voto, o ministro Celso de Mello afirma que quando o Estado deixa de cumprir uma imposição estabelecida pelo texto constitucional, trata-se de um "comportamento revestido da maior gravidade político-jurídica, eis que, mediante inércia, o Poder Público também desrespeita a Constituição, também ofende direitos que nela se fundam e também impede, por ausência de medidas concretizadoras, a própria aplicabilidade dos postulados e princípios da Lei Fundamental” (STF, ADPF 45, Rel. Ministro Celso de Mello, DJ de 29.04.2004).

Não se está a falar que é atribuição do STF formular e implementar políticas públicas, certo que se tratam de tarefas primariamente atribuídas ao Legislativo e Executivo. No entanto, salienta o ministro, tais incumbências podem ser atribuídas ao Judiciário "se e quando os órgãos estatais competentes, por descumprirem os encargos políticojurídicos que sobre eles incidem, vierem a comprometer, com tal comportamento, a eficácia e a integridade de direitos individuais e/ou coletivos impregnados de estatura constitucional, ainda que derivados de cláusulas revestidas de conteúdo programático” (STF, ADPF 45, Rel. Ministro Celso de Mello, DJ de 29.04.2004).

Ressalta Mello que não se admite que o Poder Público crie "obstáculo artificial que revele o ilegítimo, arbitrário e censurável propósito de fraudar, de frustrar e de inviabilizar o estabelecimento e a preservação, em favor da pessoa e dos cidadãos, de condições materiais mínimas de existência” (STF, ADPF 45, Rel. Ministro Celso de Mello, DJ de 29.04.2004), concluindo, por fim, que o objetivo último do Estado é servir aos cidadãos e não servir a si próprio. 
Desse modo, ainda que se reconheça que a formulação e execução de políticas públicas dependam de opções políticas daqueles que foram eleitos pelo povo, não há uma liberdade absoluta para tomada de tais decisões, quer pelo legislador, quer pelo Poder Executivo. Ou seja, nos casos em que sua inércia acabar por tornar letra morta o texto constitucional no que diz respeito à garantia de direitos sociais, haverá uma afronta ao texto constitucional e, portanto, justificável a atuação do Poder Judiciário.

Assim, a liberdade de conformação do legislador deve se dar dentro da moldura constitucional, de modo a realizar a Constituição. Não há liberdade na sua inércia, mas apenas no modo em que se realizará os direitos constitucionais.

O ministro Celso de Mello, em outro momento, se manifestou no sentido de que "embora resida, primariamente, nos poderes Legislativo e Executivo, a prerrogativa de formular e executar políticas públicas, revela-se possível, no entanto, ao Poder Judiciário determinar, ainda que excepcionalmente, principalmente nos casos de políticas públicas definidas pela própria Constituição, sejam as mesmas implementadas pelos órgãos estatais inadimplentes, cuja omissão - por importar em descumprimento dos encargos político-jurídicos que sobre eles incidem em caráter mandatório mostra-se apta a comprometer a eficácia e a integridade de direitos sociais impregnados de estatura constitucional” (STF, RE 436.996, Rel. Ministro Celso de Mello, DJ de 3.2.2006). ${ }^{20}$

Ainda, é de se trazer à colação a decisão do ministro Gilmar Mendes, quando do julgamento do Agravo Regimental na Suspensão de Liminar 47, cuja ementa se transcreve:

Suspensão de Liminar. Agravo Regimental. Saúde pública. Direitos fundamentais sociais. Art. 196 da Constituição. Audiência Pública. Sistema Único de Saúde SUS. Políticas públicas. Judicialização do direito à saúde. Separação de poderes. Parâmetros para solução judicial dos casos concretos que envolvem direito à saúde. Responsabilidade solidária dos entes da Federação em matéria de saúde. Ordem de regularização dos serviços prestados em hospital público. Não comprovação de grave lesão à ordem, à economia, à saúde e à segurança pública. Possibilidade de ocorrência de dano inverso. Agravo regimental a que se nega provimento (STF, SL 47 AgR, Rel. Ministro Gilmar Mendes, DJU 30.4.2010).

Na referida decisão entendeu o ministro que o Judiciário pode decidir sobre o fornecimento de outro medicamento ou tratamento diversamente do custeado pelo SUS e, nesse caso, “ao deferir uma prestação de saúde incluída entre as políticas sociais e econômicas formuladas pelo Sistema Único de Saúde (SUS), o Judiciário não está criando política pública, mas apenas determinando o seu cumprimento” (STF, SL 47 AgR, Rel. Ministro Gilmar Mendes, DJU 30.4.2010). Afirmou, ainda, que era evidente, no caso em tela, a existência de um direito subjetivo público a determinada política pública de saúde. 
O Superior Tribunal de Justiça também já se manifestou em controle efetivo de orçamento público, para que se destinem verbas específicas a realização de finalidades constitucional:

\section{ADMINISTRATIVO E PROCESSO CIVIL - AÇÃO CIVIL PÚBLICA - ATO ADMINISTRATIVO DISCRICIONÁRIO: NOVA VISÃO.}

1. Na atualidade, o império da lei, e o seu controle, a cargo do Judiciário, autoriza que se examinem, inclusive, as razões de conveniência e oportunidade do administrador.

2. Legitimidade do Ministério Público para exigir do Município a execução de política específica, a qual se tornou obrigatória por meio da resolução do Conselho Municipal dos Direitos da Criança e do Adolescente.

3. Tutela específica para que seja incluída verba no próximo orçamento, a fim de atender a propostas políticas certas e determinadas.

4. Recurso especial provido. (STJ, Resp 493.811, Rel. Ministra Eliana Calmon, DJ de 15.3.2004).

Verifica-se que o STJ admitiu a possibilidade de controle judicial de políticas públicas através do orçamento, inclusive direcionando verbas do próximo orçamento. $\mathrm{O}$ valor a ser destinado e a política específica a serem adotados, estes sim, ficam na discricionariedade do administrador. Mas não há discricionariedade em não realizar uma política pública exigida constitucionalmente. Esta é vinculante e por isso andou bem o STJ ao exigir destinação específica para atender objetivo da Carta Constitucional.

No Recurso Especial 1.041.197-MS, o ministro Humberto Martins justifica a possibilidade do controle de políticas públicas pelo Poder Judiciário em casos excepcionais, quando a administração pública age sem razão ou extrapola os limites de sua competência, casos em que o Judiciário poderá corrigir tal situação (STJ, REsp 1.041.197, Rel. Ministro Humberto Martins, DJ de 16.9.2009).

Aduz o ministro que o princípio da Separação dos Poderes deve ser lido à luz da nova Constituição, que atribui novos papéis ao Estado na realização dos direitos sociais e, ao exigir uma atuação ativa da Administração Pública, acaba por exigir uma atuação mais forte de fiscalização do Poder Judiciário. Não se quer dizer que a atuação do Judiciário no controle de políticas públicas pode se dar de forma indiscriminada, mas, quando a Administração Pública violar direitos fundamentais, a "interferência do Poder Judiciário é perfeitamente legítima e serve como instrumento para restabelecer a integridade da ordem jurídica violada (STJ, REsp 1.041.197, Rel. Ministro Humberto Martins, DJ de 16.9.2009).

Ainda, em seu voto, afirma o ministro Humberto Martins que deveria a Administração Pública ter previsto orçamento específico para suprir a falta de equipamentos hospitalares, evitando ações como a presente, não cabendo ao Judiciário restar 
passivo frente a tais demandas e a omissão injustificada da administração em efetivar políticas públicas (STJ, REsp 1.041.197, Rel. Ministro Humberto Martins, DJ de 16.9.2009).

Nesse mesmo sentido, o ministro Luiz Fux já se manifestou defendendo que a determinação judicial do dever de coleta de lixo, na medida em que causa prejuízo à saúde, não significa ingerência do Judiciário na esfera da administração, uma vez que "não há discricionariedade do administrador frente aos direitos consagrados, quiçá constitucionalmente" já que "nesse campo a atividade é vinculada sem admissão de qualquer exegese que vise afastar a garantia pétrea” (STJ, REsp 575998, Rel. Ministro Luiz Fux, DJ de 16.11.2004).

Verifica-se, desse modo, que o Judiciário brasileiro avançou bem no sentido de enfrentar as questões de políticas públicas que envolvem direitos fundamentais, especialmente nos casos de inércia ou má atuação dos poderes eleitos.

\section{Considerações finais}

Não obstante as críticas que o Judiciário brasileiro vem sofrendo, no sentido de que está se imiscuindo em questões políticas, em ofensa ao princípio da separação dos poderes e, ainda, que, por não ser um poder eleito pelo povo, não poderia interferir nessas questões, o que se verifica no presente artigo é que a transferência de decisão do Parlamento para o Judiciário decorre em virtude do fenômeno da judicialização da política.

Em que pese a teoria da autorrestrição judicial, verifica-se que no contexto da Constituição Federal de 1988 a mesma não se sustenta, eis que a partir da Carta Magna deve se dar um novo papel ao Judiciário brasileiro, que passa a exercer um importante papel na realização dos direitos fundamentais. O princípio da separação dos poderes deve, então, ser analisado a partir da Constituição, com a ideia de controles recíprocos entres os poderes e não mais a ideia de separação rígida entre os mesmos.

Ao se defender a possibilidade do Judiciário intervir em políticas públicas, não se quer colocar o primeiro como salvador da pátria ou como protagonista de um processo de transformação e de redução de desigualdades em nossa sociedade, e sim que ele atue junto com os outros poderes e possa, por meio da efetivação dos direitos fundamentais sociais, melhorar o processo democrático existente.

Até porque, muitas vezes, é o Judiciário quem está mais próximo dos cidadãos, que podem, diretamente, lá reivindicar a satisfação de seus direitos constitucionais. Assim, a efetivação dos direitos sociais pela jurisdição constitucional pode muito bem promover o processo democrático, "by directing political attention to interests that would otherwise be disregarded in ordinary political life" 11 (Sunstein, 2004, p. 228), acreditando Sunstein que mesmo em países pobres, é possível a proteção dos direitos sociais, tendo a jurisdição constitucional vários modos para fazê-lo. ${ }^{22}$ 
Conclui-se que em sede de controle concentrado de constitucionalidade, deve a Corte Constitucional brasileira, ${ }^{23} \mathrm{em}$ caso de omissão do governo na realização dos direitos sociais, determinar que este implemente políticas públicas progressivas razoáveis para assegurar que as minorias possam usufruir dos direitos sociais, especialmente em relação a direitos sociais, como moradia e trabalho, que exigem políticas públicas progressivas. Pois, nesses casos, é complicado garantir o direito à moradia ou ao emprego judicialmente, mas o cidadão tem o direito de ver que o governo está implementando políticas públicas progressivas para promoção e realização desses direitos. ${ }^{24}$

Entretanto, se o Estado não consegue demonstrar que está realizando essas políticas públicas, ou se ficar comprovado que tinha capacidade financeira para fazer algo melhor e maior, então poderá o Judiciário declarar que o governo está violando a Constituição. ${ }^{25}$

Por outro lado, como o Supremo Tribunal Federal esvaziou as funções da Ação Declaratória de Inconstitucionalidade por Omissão, é certo que os cidadãos não podem ficar desprotegidos, devendo o Poder Judiciário, por meio do controle difuso de constitucionalidade das leis, determinar a realização dos direitos sociais, mesmo que individualmente, daqueles que batem às suas portas, principalmente em relação àqueles direitos que podem ser garantidos de imediato, como a saúde e a educação (até porque o direito à vida, quando chega ao Judiciário para ser protegido, na maior parte das vezes é questão emergencial).

Se o Legislativo, o Executivo e o Judiciário se comunicarem, os dois primeiros poderão, inclusive, verificar as necessidades mais urgentes dos cidadãos, que muitas vezes ficam esquecidas nos debates políticos do dia a dia, e procurar, assim, paralelamente à proteção imediata garantida pelo Poder Judiciário, promover políticas sociais em longo prazo para garantir os direitos sociais ao máximo de cidadãos possível.

Por outro lado, cumpre asseverar que sendo a Constituição um documento político caberá sim, ao Judiciário, tomar algumas opções políticas, as quais, entretanto, deverão ser fundamentadas em princípios escolhidos pelo próprio povo no momento constituinte. 
1 Como exemplo recente, pode ser citado o caso da Nova Zelândia, que adotou um Bill of Rights, passando este a servir como parâmetro do controle de constitucionalidade das demais leis.

2 Nesse sentido: "There is hardly a political question in the United States which does not sooner or later turn into a judicial one” (Alexis Tocqueville, Democracy in America, Vintage Books, 10 ed. 1961).

3 No Brasil, o maior exemplo diz respeito a questões relacionadas ao direito fundamental à saúde, sendo o Judiciário questionado e criticado por estar intervindo em esfera de políticas de saúde.

$4 \mathrm{O}$ aumento das ações relacionadas a questões de gênero e violência doméstica caracteriza a judicialização das relações sociais privadas: "the way in which thousands of ordinary women have increasingly resorte do the lower-level courts for protection of their individual right to life and physicial integrity in situations of domestic violence" (Macaulay, 2005, p. 211).

5 A respeito confira-se a seção de notícias no site: www.stf.gov.br. Acesso em: 28 fev. de 2008.

6 Ver, a respeito: Estefânia Maria de Queiroz Barboza. Stare decisis, integridade e segurança jurídica: Reflexões críticas a partir da aproximação dos sistemas de common law e civil law. Tese de Doutorado, PUCPR, 2011.

7 Nesse sentido, confira-se: “The term 'judicial activism' is, however, much more commonly used to refer not to how busy a court is but to how willing its judges are to develop the law. In that sense it is a controversial concept, for two reasons. First, judges are (in most countries) not elected and in a liberal democracy the conventional view persists that only persons elected to Parliament, or serving in an executive which is accountable to Parliament, should make laws. (The extreme form of this convention is the declaratory theory of law, according to which judges never create law at all - they merely find law which has always existed but been hidden from view under layers of misrepresentation. In the United Kingdom this 'fairy tale' was definitively debunked by Lord Reid in 1972). Secondly, what amounts to 'developing' the law can itself be a matter for considerable disagreement: is a fully reasoned decision to preserve an existing rule, taken after long deliberation, an example of activism or not, and in situations where the judges are agreed that the law should be developed, what criteria should be employed to assess whether the chosen development is the appropriate one? As has been noted by Justice Heydon of the High Court of Australia 'the relevant factors are indeterminate and to some degree they can conflict". Brice Dickson, Judicial Activism in The House of Lords 1995-2007, in: Brice Dickson, ed., Judicial Activism in Common Law Supreme Courts (New York: Oxford University Press, 2007, p. 367).

8 Christopher Wolfe define o ativismo judicial convencional como aquele no qual "judges ought to decide cases, not avoid them, and thereby use their Power broadly to further justice- that is, to protect human dignity - especially by expanding equality and personal liberty. Activist judges are committed to provide judicial remedies for a wide range of social wrongs and to use their power, especially the power to give content to general constitutional guarantees, to do so" (1997, p. 2). Mais a frente conclui que: "judicial activism may be defined in terms of either the relation of a judicial decision to the Constitution or the manner in which judges exercise what is conceded to be a broadly political, discretionary power. The definition on which I place the greater emphasis will be dissatisfying to most contemporary constitutional scholars, who subscribe to different conceptions of the nature of judicial power and of the evolution of judicial review in American history" (1997, p. 31).

9 Essa é a mesma lógica que justifica que os países europeus se autolimitem em relação à sua própria soberania, favorecendo uma autoridade internacional independente. Assim, a conivência dos países europeus em aceitar limitar sua soberania em prol de uma autoridade internacional e contramajoritária, no que diz respeito aos direitos humanos, é justificada, segundo Moravcsik, pelo fato de que os governos buscam a coerção internacional quando um compromisso internacional efetivamente reforça as preferências políticas de um governo específico num determinado tempo contra futuras alternativas políticas domésticas. Ou seja, a autolimitação dos Estados pela adesão a tratados internacionais de direitos humanos não é um movimento em busca de um altruísmo moral, mas, ao contrário, os governos vão se valer dessa tática quando os benefícios de reduzir futuras incertezas políticas pesam mais que os custos de limitação da soberania de sua associação. E continua explicando que o fato de se auto-obrigar ou de se autocomprometer é mais utilizado em democracias recém-estabelecidas, que acabam por ter grande interesse na estabilização democrática da política interna contra ameaças antidemocráticas (Moravcsik, 2000, p. 218-249). 
10 BRASIL. STF - MS 26602 - Rel. Ministro Eros Grau - DJU 17.10.2008. Disponível em: www.stf.gov.br. Acesso em: 23 jun. 2010. STF - MS26603 - Rel. Ministro Celso de Mello - DJU 18.12.2008. Disponível em: www.stf.gov.br. Acesso em: 23 jun. 2010. STF - MS 26604 - Rel. Ministra Carmen Lúcia DJU 3.10.2008. Disponível em: www.stf.gov.br. Acesso em: 23 jun. 2010.

11 No mesmo sentido, confira-se Luiz Werneck Vianna, Maria Alice Rezende de Carvalho, Manuel Palácios Cunha Melo, Marcelo Baumann Burgos, A judicialização da política e das relações sociais no Brasil (Rio de Janeiro: Revan, 1999, p. 103). The New Constitutionalism and the Judicialization of Pure Politics Worldwide. Fordham Law Review, v. 75, n. 2, 2006, p.754.: "the judicialization of mega-politics, and the transition to juristocracy more generally, is first and foremost a political, not a juridical, phenomenon" [“a judicialização da megapolítica, e a transição para a juristocracia, de um modo geral, é antes de tudo e principalmente um fenômeno político, e não um fenômeno jurídico”]. Disponível em: http://ssrn.com/abstract=951610. Acesso em: 20 fev. 2008.

12 Ver, a respeito: Estefânia Maria de Queiroz Barboza, Jurisdição Constitucional: Entre constitucionalismo e democracia (Belo Horizonte: Editora Fórum, 2007).

13 Veja-se que tal afirmativa não pode ser pensada para o controle concentrado de constitucionalidade no Brasil, onde as decisões, em regra, têm eficácia erga omnes.

14 "In a later case, Marshall noted that the courts have jurisdiction 'when any questions respecting them (the constitution, laws, and treaties of the United States) shall assume such a form that the judicial power is capable of acting on it. That power is capable of acting only when the subject is submitted to it by a party who asserts his rights in the form prescribed by law. It them becomes a case, and the constitution declares that the judicial power shall extend to all cases arising under the constitution, laws, and treaties of the United States" ["Em um caso posterior, Marshall notou que as cortes têm jurisdição quando quaisquer questões respeitando-os (a constituição, as leis, e dos tratados dos Estados Unidos) devem assumir tal forma que o poder judicial é capaz de agir. Essa força é capaz de agir somente quando o assunto é submetido ao judiciário por um partido que afirma seus direitos na forma prescrita pela lei. Então se torna um caso, e a constituição declara que o poder judiciário deve ser estendido a todos os casos submetidos à constituição, às leis e aos tratados dos Estados Unidos”] (Wolfe, 1994, p. 103).

15 Importa salientar que o Supremo Tribunal Federal já admite a "interpretação conforme a Constituição", bem como a "interpretação sem redução de texto", por meio das quais se busca dar uma interpretação à lei que seja compatível com a Constituição.

16 Mais uma vez, Ricardo Haro: "Asimismo señaló que "por tal motivo, en las causas en que -como en el sub litese impugnan actos cumplidos por otros poderes en el ámbito de las facultades que les son privativas, la función jurisdiccional no alcanza al modo del ejercicio de tales atribuciones, en cuanto de otra manera se haría manifiesta la invasión del ámbito de las facultades propias de las otras autoridades de la Nación (cita a Fallos, p. 254-45) (...) El Poder Judicial ejerce un verdadero control de constitucionalidad cuando verifica si los actos de los otros dos poderes se han cumplido dentro de sus respectivas esferas de actuación, lo cual exige um delicado ejercicio de interpretación constitucional y una responsabilidad de la Corte como último intérprete de la Constitución, que permite definir en qué medida - si es que existe alguna- el ejercicio de ese poder puede ser sometido a revisión judicial, facultad esta última que sólo puede ser ejercida cuando haya mediado alguna violación normativa que ubique los actos de los otros poderes fuera de las atribuciones que la Constitución les confiere o del modo en que esta autoriza a ponerlas en práctica" (...) pues "la tradicional jurisprudencia del Tribunal postula que las razones de oportunidad, mérito o conveniencia tenidas en cuenta por los otros poderes del estado para adoptar decisiones que le son propias, no está sujetas al control judicial (cita a Fallos: 98-20; 147-402; 150-189; 160-247; 238-160; 247-121; 251-21; 275-218; 295-814; 301 341; 302-457; 303-1029; 308-2246, entre muchos otros). Asimismo en destacado pronunciamiento, "Bussi" del 11 de octubre de 2001 (F. 324-3358), la CS reafirmó que "es inherente a las funciones de un tribunal de justicia, interpretar las normas que confieren las facultades privativas de los otros poderes, para determinar su alcance, sin que tal tema constituya una "cuestión política", inmune al ejercicio de la jurisdicción” (Haro, 2008).

17 No mesmo sentido, confira-se Ran Hirschl, Juristocracy - Political, not Juridical. The Good Society, v. 13, n. 13, 2004.

18 A respeito do controle do Poder Judiciário, conferir Paulo Bonavides, Jurisdição Constitucional e Legitimidade. Estudos Avançados, v. 51, n. 18, São Paulo, 2004. 
19 Nessa perspectiva, sobre a separação de questão política e questão jurídica Baracho Júnior afirma que "é razoável imaginar que o Poder Judiciário não pretenda ser responsabilizado pelas dificuldades econômicas que uma decisão judicial possa acarretar. Isso, inclusive foi expressamente assumido por importantes membros da magistratura, quando dos primeiros debate sobre o plano de racionamento de energia elétrica. É sem dúvida importante preservar a integridade do Poder Judiciário, mas é também essencial assegurar o exercício dos direitos fundamentais, ainda que para isso, em determinadas circunstâncias, seja necessário, com fundamento em princípios constitucionais, barrar políticas públicas” (2003, p. 343).

20 STF - RE 436.996 - Rel. Ministro Celso de Mello - DJU 3.2.2006. Disponível em: www.stf.gov.br. Acesso em: 18 jul. 2010. No mesmo sentido: STF - AgRgRE 603.575 - Rel. Ministro Eros Grau - DJU 14.5.2010. Disponível em: www.stf.gov.br. Acesso em: 18 jul. 2010. STF-AgRgRE 464.143 - Rel. Ministra Ellen Gracie - DJU 19.2.2010. Disponível em: www.stf.gov.br. Acesso em: 18 jul. 2010. STF - RE 594.018 - Rel. Ministro Eros Grau - DJU 7.8.2009. Disponível em: www.stf.gov.br. Acesso em: 18 jul. 2010. STF AgRgRE 595.595 - Rel. Ministro Eros Grau - DJU 29.5.2009. Disponível em: www.stf.gov.br. Acesso em: 18 jul. 2010.

21 “... por dirigir a atenção política a interesses que, de outro modo, seriam negligenciados na vida política cotidiana.”

22 No mesmo sentido: "Pela sua natureza, o debate judicial permite o avanço da democracia ao permitir as discussões de temas relevantes. Seja lá qual for a nossa opinião a respeito de temas, como censura, liberdade de imprensa, aborto, direitos de minorias, direito de greve, etc., sua submissão a uma discussão judicial amplia o espaço de democracia, porque exige, com mais ou menos sucesso, a racionalidade das propostas divergentes”. José Reinaldo de Lima Lopes, Judiciário, democracia, políticas públicas. Revista de Informação Legislativa, a. 31, n. 122, 1994, p. 263-264.

23 No Brasil o Supremo Tribunal Federal acumula as funções de Corte Constitucional e de cúpula do Poder Judiciário.

24 Ver: Sunstein, 2004, p. 197ss.

25 "If, for example, the state does little to provide people with decent food and health care, and if it is financially able to do much more, it would seem that the state has violated the constitutional guarantee" ["Se, por exemplo, o Estado fizesse pouco para fornecer às pessoas alimentos decentes e cuidados de saúde, e se fosse financeiramente capaz de fazer muito mais, parece que o Estado teria transgredido a garantia constitucional”] (Sunstein, 2004, p. 219).

\section{REFERÊNCIAS BIBLIOGRÁFICAS}

ARANTES, Rogério Bastos. Direito e política: o Ministério Público e a defesa dos direitos coletivos. Rev. Bras. Ci. Soc., São Paulo, v. 14, n. 39, Feb. 1999. Disponível em: www.scielo.br/scielo.php?script= sci_arttext\&pid=S0102-9091999000100005\&lng=en\&nrm=iso. Acesso em: 20 set. 2010. Constitutionalism, the expansion of Justice and the Judicialization of Politics in Brazil. In: Rachel Sieder; Line Schjolden; Alan Angell. The Judicialization of Politics in Latin America. Nova York: Palgrave Macmillan, 2006.

BARACHO JÚNIOR, José Alfredo de Oliveira. A interpretação dos direitos fundamentais na Suprema Corte dos EUA e no Supremo Tribunal Federal. In: José Adércio Leite Sampaio. (Org.) Jurisdição constitucional e direitos fundamentais. Belo Horizonte: Del Rey, 2003.

BUCCI. Maria Paula Dallari. O conceito jurídico de política pública em direito. In: (Org.) Políticas públicas: Reflexões sobre o conceito jurídico. São Paulo: Saraiva, 2006. CANOTILHO, José Joaquim Gomes. Direito Constitucional e Teoria da Constituição. 3. ed. Coimbra: Almedina, 2000. 
CAPPELlETTI, M. Juízes legisladores? Traduzido por Carlos Alberto Álvaro de Oliveira. Porto Alegre: Sérgio Antonio Fabris, 1999.

CARVALHO, Ernani Rodrigues de. Em busca da judicialização da política no Brasil: apontamentos para uma nova abordagem. Rev. Sociol. Polit., Curitiba, n. 23, 2004. Disponível em:

www.scielo.br/scielo.php?script=sci_arttext\&pid=S0104-44782004000200011\&1ng=en\&nrm=iso. Acesso em: 29 fev. 2008.

CHEVAlLiER, Jacques. O Estado Pós-Moderno. Traduzido por Marçal Justen Filho. Belo Horizonte: Fórum, 2009.

COMPARATO, Fábio Konder. Ensaio sobre o juízo de constitucionalidade de políticas públicas. Revista de Informação Legislativa, v. 35, n. 138, abr./jun. 1998.

DICKSON, Brice. Judicial Activism in The House of Lords 1995-2007. In: Brice Dickson. (Ed.) Judicial Activism in Common Law Supreme Courts. New York: Oxford University Press, 2007.

DWORKIN, Ronald. Los Derechos en serio. Traduzido para o espanhol por Marta Guastavino. 5. reimp. Barcelona: Editorial Ariel, 2002.

GILlman, Howard. How Political Parties can use the Courts to advance their agendas: Federal Courts in the United States, 1875-1891. American Political Science Review, v. 96, Issue 3, Sept. 2002.

HARO, Ricardo. Las Cuestiones Políticas: ¿Prudencia o Evasion Judicial?. Disponível em: www.acaderc.org.ar/doctrina/articulos/artcuestionespoliticas. Acesso: 14 ago. 2008.

HIRSCHL, Ran. Towards Juristocracy: The Origins and Consequences of the New Constitutionalism. Cambridge: Harvard University Press, 2004.

The New Constitutionalism and the Judicialization of Pure Politics Worldwide. Fordham Law Review, v. 75, n. 2, 2006, p. 723. Disponível em: http://ssrn.com/abstract=951610. Acesso em: 20 fev. 2008 .

. "Juristocracy" - Political, not Juridical. The Good Society, v. 13, n. 13, 2004.

KRELL, Andreas Joachim. Direitos Sociais e Controle Judicial no Brasil e na Alemanha: os (des)caminhos de um Direito Constitucional "comparado". Porto Alegre: Sergio Antonio Fabris, 2002.

LOPES, José Reinaldo de Lima. Judiciário, democracia, políticas públicas. Revista de Informação Legislativa, a. 31, n.122, 1994.

MACAUlaY, Fiona, Private Conflicts, Public Powers: domestic violence in the Courts in Latin America. In: Rachel Sieder; Line Schjolden; Alan Angell. The Judicialization of Politics in Latin America. Nova York: New York: Palgrave Macmillan, 2005.

MACIEL, Débora Alves; KOERNER, Andrei. Sentidos da Judicialização da Política: duas análises. Lua Nova, n. 57, 2002.

MANCUSO, Rodolfo de Camargo. A ação civil pública como instrumento de controle judicial das chamadas políticas públicas. In: Edis Milaré. (Coord.) Ação Civil Pública: Lei 7.347 - 15 anos. São Paulo: Editora Revistas dos Tribunais, 2001.

MAUÉS, Antonio G. Moreira; LEITÃO, Anelice F. Belém. Dimensões da judicialização da política no Brasil: As ADIns dos partidos políticos. Revista de Informação Legislativa, a. 41, n. 163, 2004.

MELLO, Cláudio Ari. Democracia constitucional e direitos fundamentais. Porto Alegre: Livraria do Advogado, 2004.

MORAVCSIK, Andrew. The Origins of Human Rights Regimes: Democratic Delegatin. In: Postwar Europe. International Organization. v. 54, n. 2 (Sspring, 2000), p. 218. Disponível em:

www.jstor.org/stable2601297. Acesso em: 21 fev. 2008.

SOUZA NETO, Cláudio Pereira et al. Teoria da Constituição: Estudos sobre o lugar da política no direito constitucional. Rio de Janeiro: Lumen Juris, 2003.

SUNSTEIN, Cass R. The Second Bill of Rights: FDR's Unfinished Revolution and Why we Need it More than Ever. Nova York: Basic Books, 2004.

. Social and Economic Rights? Lessons from South Africa. Public Law and Legal Theory

Working Paper n. 12. Disponível em: www.law.uchicago.edu/Lawecon/index.html. Acesso em: 10 ago. 2006.

TATE, C. Neal; VALLINDER, Torbjörn. The Global Expansion of Judicial Power: The Judicialization of Politics. In: C. Neal Tate; Torbjörn Vallinder. (Ed.) The Global Expansion of Judicial Power. Nova York: New York University Press, 1995.

VALLINDER, Torbjörn. When the Courts go marching in. In: C. Neal Tate; Torbjörn Vallinder. (Ed). The Global Expansion of Judicial Power. Nova York: New York University Press, 1995.

VERBICARO, Loiane Prado. Um estudo sobre as condições facilitadoras da judicialização da política no Brasil. Revista DireitoGV, n. 4, 2008. 
VIANNA, Luiz Werneck; BURGOS, Marcelo Baumann; SALLES, Paula Martins. Dezessete anos de judicialização da política. Tempo Soc., São Paulo, v. 19, n. 2, nov. 2007. Disponível em: www.scielo.br/scielo.php?script $=$ sci_arttext\&pid $=$ S0103-20702007000200002\&lng $=$ en\&nrm $=$ iso. Acesso em: 20 set. 2010.

VIANNA, Luiz Werneck; CARVALHO, Maria Alice Rezende de; MELO, Manuel Palácios Cunha; BURGOS, Marcelo Baumann. A judicialização da política e das relações sociais no Brasil. Rio de Janeiro: Revan, 1999.

WALDRON, Jeremy. Law and Disagreement. Oxford: Oxford University Press, 1999a.

. The core of the case against judicial review. Yale Law Journal, v. 115, 2006.

WHITTINGTON, Keith E. Interpose your friendly hand: Political Supports for the Exercise of Judicial Review by the United States Supreme Court. American Political Science Review, v. 99, n. 4.

WOLFE, Christopher. The Rise of Modern Judicial Review: from constitutional interpretation to judge-made law. Rev. ed. Maryland: Littlefield Adams Quality Paperbacks, 1994.

.WOLFE, Christopher. Judicial Activism: Bulwark of Freedom or Precarious Security? Maryland:

Rowman \& Littlefield Publishers, 1997.

Rua Konrad Adenauer, n. 442

Tarumã - 82821-020

Curitiba - PR - Brasil

estefaniaqueirozauol.com.br

Rua Rubens dos Santos Costa, n. 32 ap. 1202

Cristo Rei - 80050-500

Curitiba - PR - Brasil

kkozickiduol.com.br

\section{Estefânia Maria de Queiroz Barboza}

Mestre e Doutora em Direito Econômico E SOCIOAMBIENTAL PELA PUCPR

Professora de Direito Constitucional dos Programas DE Graduação E Mestrado das Faculdades InTEgRadas DO BRASIL (UNIBRASIL)

VISITING RESEARCHER NA OSgOOdE HALL LAW SCHOOL (YoRK UnIVERSITY), TORONTO, CANADÁ, 2008/2009

Katya Kozicki

MEstre e Doutora em diREITO PELA UFSC

PROFESSORA DOS PROGRAMAS DE GRADUACCÃO E PÓS-GRADUACĀO EM DIREITO DA UFPR E PUCPR

Visiting Researcher Associate, Center for the Study of DEMOCRACY, UNIVERSITY OF WESTMINSTER, LONDRES, 1999/2000 